\title{
ANALISIS EKONOMI PETERNAKAN AYAM BROILER DI KOTA PEKANBARU
}

\section{Economic Analysis of Broiler Farm in Pekanbaru City}

\author{
Sri Ayu Kurniati, Sisca Vaulina \\ Program Studi Agribisnis, Fakultas Pertanian, Universitas Islam Riau \\ Jl. Kaharuddin Nasution No. 113 Pekanbaru 28284 \\ Email: sriayukurniati@agr.uir.ac.id \\ [Diterima: November 2021; Disetujui: Desember 2021]
}

\begin{abstract}
Broiler farms have the potential to be developed but there are obstacles such as fluctuations in input and output prices, capital problems, and various production risks that will have a big impact on production yields. The purpose of the study was to determine the economic analysis of broiler farming in Pekanbaru City. The study used a survey method on 80 farmers in the Districts of Rumbai, Rumbai Pesisir, and Tenayan Raya. Data were analyzed descriptively, qualitatively and quantitatively and used BEP and MOS. The results showed that the total cost of production was IDR 80,431,995 with the highest variable cost for purchasing DOC. Revenue received was IDR 206,200,750 and was obtained from the sale of live chickens. The chicken manure was used as organic fertilizer. The profit value was IDR $125,768,755$ and the $\mathrm{R} / \mathrm{C}$ ratio was 2.56 . The results showed that the business is feasible to be continued and developed. The BEP unit was 586 chickens with a price of IDR 331 and revenue of IDR $13,860,393 / \mathrm{kg}$. For the chicken manure, the unit BEP value was $990 \mathrm{~kg}$ with price of IDR 23 and revenue of IDR 237,780. The MOS value for broiler farming is in the high category, so it is still within the safe limit.
\end{abstract}

Keywords: Broiler farm, RCR, BEP, MOS

\begin{abstract}
Peternakan ayam broiler berpotensi untuk dikembangkan namun terdapat kendala seperti fluktuasi harga input dan output, permasalahan modal dan berbagai risiko produksi yang sangat besar pengaruhnya pada hasil produksi. Tujuan penelitian untuk mengetahui analisis ekonomi usaha peternakan ayam broiler di Kota Pekanbaru. Penelitian menggunakan metode survei pada 80 peternak di Kecamatan Rumbai, Rumbai Pesisir dan Tenayan raya. Data dianalisis secara deskriptif kualitatif dan kuantitatif, BEP dan MOS. Hasil penelitian menunjukkan bahwa total biaya produksi sebesar Rp 80.431.995 dengan biaya variabel tertinggi adalah pembelian DOC. Penerimaan sebesar Rp 206.200.750 yang diperoleh dari penjualan ayam hidup kotoran ayam yang digunakan sebagai pupuk organik. Nilai keuntungan sebesar Rp 125.768.755 dan R/C ratio adalah 2,56 sehingga usaha dianggap layak untuk dilanjutkan dan dikembangkan. BEP unit sebesar 586 ekor ayam dengan harga Rp 331 dan penerimaan Rp 13.860.393/kg. sedangkan untuk kotoran ayam didapat nilai BEP unit sebanyak $990 \mathrm{~kg}$ dengan harga $\mathrm{Rp} 23$ dan penerimaan $\mathrm{Rp}$ 237.780. Nilai MOS usaha peternakan ayam broiler termasuk kategori tinggi sehingga masih berada pada batas aman.
\end{abstract}

Kata kunci: Analisis, Ekonomi, Broiler, BEP, MOS

\section{PENDAHULUAN}

Peternakan merupakan subsektor
pertanian yang sangat potensial untuk
dikembangkan karena memberi kontribusi
terhadap pendapatan daerah, menyerap tenaga
kerja, meningkatkan produktivitas masyarakat
dan penyediaan kebutuhan protein hewani,
Daging, susu, telur adalah produk utama yang

menjadi andalan dan tolok ukur perkembangan peternakan di Indonesia (Saragih dan Sebastian, 2008). Berdasarkan data SUSENAS tahun 2019 bahwa tingkat konsumsi daging ayam sebesar $12,79 \mathrm{~kg} / \mathrm{kapita} / \mathrm{tahun}$, hal ini mengindikasikan bahwa peningkatan jumlah penduduk akan meningkatkan kesadaran gizi masyarakat untuk mengkonsumsi protein hewani, yang salah satunya berasal dari ayam. 
Salah satu kegiatan penyediaan pangan hewani yang dapat meningkatkan pendapatan masyarakat dan memiliki daya saing yaitu peternakan ayam broiler. Ayam broiler atau ayam ras pedaging di Kota Pekanbaru merupakan jenis unggas yang memiliki jumlah populasi terbanyak dibandingkan jenis unggas lainnya yaitu sebanyak 7.410 .377 ekor atau naik 4,54\% dari tahun 2019. Tren peningkatan positif jumlah populasi ayam broiler rata-rata sebesar 2\% per tahun (Dinas Pertanian dan Perikanan, 2019). Peningkatan produksi ayam broiler akan meningkatkan pendapatan peternak, efisiensi dan keuntungan usaha. Besar kecilnya pendapatan peternak bergantung pada jumlah dan harga output yang dihasilkan.

Ayam broiler berpotensi untuk dikembangkan karena memiliki beberapa keunggulan, diantaranya: masa produksi relatif singkat, balik modal dan keuntungan lebih cepat dan peningkatan permintaan masyarakat (Putri, dkk, 2020). Namun, peternak juga menghadapi berbagai kendala seperti fluktuasi harga input dan output, permasalahan modal dan berbagai risiko produksi yang sangat besar pengaruhnya pada hasil produksi. Kemampuan dalam mengelola berbagai risiko produksi sangat diperlukan peternak untuk memaksimalkan hasil produksi dan keuntungan. Peningkatan efisiensi dilakukan dengan mengoptimalkan penggunaan sarana produksi dan penggunaan biaya produksi seefisien mungkin untuk menghasilkan output yang maksimal. Berdasarkan hal tersebut maka penelitian ini dilakukan dengan tujuan untuk mengetahui analisis ekonomi pada peternakan ayam broiler di Kota Pekanbaru.

\section{METODE PENELITIAN}

Penelitian menggunakan metode survei di Kota Pekanbaru karena memiliki jumlah populasi ayam broiler yang lebih tinggi dibandingkan daerah lainnya di Provinsi Riau, yang dilaksanakan pada bulan Desember 2020 hingga Juni 2021. Teknik pengambilan sampel secara acak sederhana (simple random sampling) kepada 80 orang peternak ayam broiler yang berada di Kecamatan Rumbai, Rumbai Pesisir dan Tenayan Raya.

Data penelitian terdiri dari data primer yang diperoleh langsung dari peternak meliputi penggunaan faktor produksi, jumlah dan harga produksi, serta data skunder yang diperoleh dari BPS, Dinas Peternakan, UPTD Kota
Pekanbaru dan literatur lain meliputi data jumlah populasi ayam broiler dan keadaan peternakan di Kota Pekanbaru.

\section{Analisis data}

Analisis ekonomi usaha peternakan ayam broiler menggunakan analisis deskriptif kualitatif dan kuantitatif, yang dimulai dari menentukan biaya produksi, penerimaaan, keuntungan, R/C Ratio, BEP, dan MOS. Biaya produksi ditentukan dengan menghitung seluruh biaya yang dikeluarkan dalam proses produksi meliputi biaya tetap dan biaya variabel, dengan rumus Soekartawi (2002):

$\mathrm{TC}=\mathrm{TFC}+\mathrm{TVC}$

Keterangan:

$\mathrm{TC}=$ Total biaya (Rp/Periode Produksi)

TFC = Biaya tetap (Rp/ Periode Produksi)

TVC = Biaya variabel $(\mathrm{Rp} /$ Periode Produksi)

Penerimaan diperoleh dari perkalian antara produksi dan harga produksi, dengan rumus:

$\mathrm{TR}=\mathrm{Y} . \mathrm{Py}$

Keterangan:

$\mathrm{TR}=$ Total penerimaan $(\mathrm{Rp} /$ Periode Produksi $)$

$\mathrm{Y}=$ Produksi dari usaha ternak ayam broiler (Rp/ Periode Produksi)

Py $=$ Harga produksi $(\mathrm{Rp} / \mathrm{kg})$

Setelah diperoleh biaya produksi dan penerimaan, maka dapat ditentukan keuntungan usaha dengan rumus:

$\pi \quad=T R-T C$

Keterangan:

$\pi=$ Keuntungan usaha peternakan ayam broiler (Rp/Periode Produksi)

$\mathrm{TR}=$ Total penerimaan $(\mathrm{Rp} /$ Periode Produksi)

$\mathrm{TC}=$ Total biaya $(\mathrm{Rp} /$ Periode Produksi)

Efisiensi usaha peternakan ayam broiler ditentukan dengan rumus:

$\mathrm{R} / \mathrm{C}$ Ratio $=\mathrm{TR} / \mathrm{TC}$

dengan kriteria:

a. $\mathrm{R} / \mathrm{C}$ ratio > 1 , usaha menguntungkan, efisien dan layak dikembangkan

b. $\mathrm{R} / \mathrm{C}$ ratio $<1$, usaha tidak menguntungkan, tidak efisien dan tidak layak dikembangkan

c. $\mathrm{R} / \mathrm{C}$ ratio $=1$, usaha berada pada titik impas

BEP (Break Even Point) adalah kondisi suatu usaha yang tidak mendapatkan 
keuntungan maupun kerugian, yang dibedakan atas BEP Unit, BEP Harga dan BEP Penerimaan:

BEP unit $(\mathrm{kg})=\frac{F C}{\mathrm{P}-\mathrm{AVC}}$

Keterangan:

FC = Biaya tetap usaha ternak ayam broiler (Rp/Periode produksi)

$\mathrm{P} \quad=$ Harga jual ayam broiler $(\mathrm{Rp} / \mathrm{kg})$

$\mathrm{AVC}=$ Biaya variabel per unit ayam broiler

$\mathrm{BEP}$ harga $(\mathrm{Rp})=\frac{F C}{\mathrm{p}}$

Keterangan:

$\mathrm{FC}=$ Biaya tetap usaha ternak ayam broiler (Rp/Periode produksi)

$\mathrm{P} \quad=$ Harga jual ayam broiler $(\mathrm{Rp} / \mathrm{kg})$

BEP Penerimaan $(\mathrm{Rp} / \mathrm{Kg})=\frac{\mathrm{FC}}{1-V C / S}$
Keterangan:

FC = Biaya tetap usaha ternak ayam broiler (Rp/Periode produksi)

$\mathrm{VC}=$ Biaya variabel usaha ternak ayam broiler (Rp/Periode produksi)

$\mathrm{S} \quad=$ Jumlah penjualan (Rp/Periode produksi)

MOS (Margin of Safety) adalah batas aman antara penjualan yang direncanakan dengan penjualan pada saat BEP:

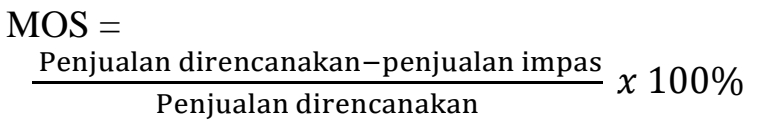

\section{HASIL DAN PEMBAHASAN}

Perhitungan analisis ekonomi peternakan ayam broiler dimulai dengan menganalisis biaya produksi meliputi biaya tetap dan biaya variabel, seperti tabel berikut:

Tabel 1. Rata-rata Biaya Produksi Peternakan Ayam Broiler di Kota Pekanbaru

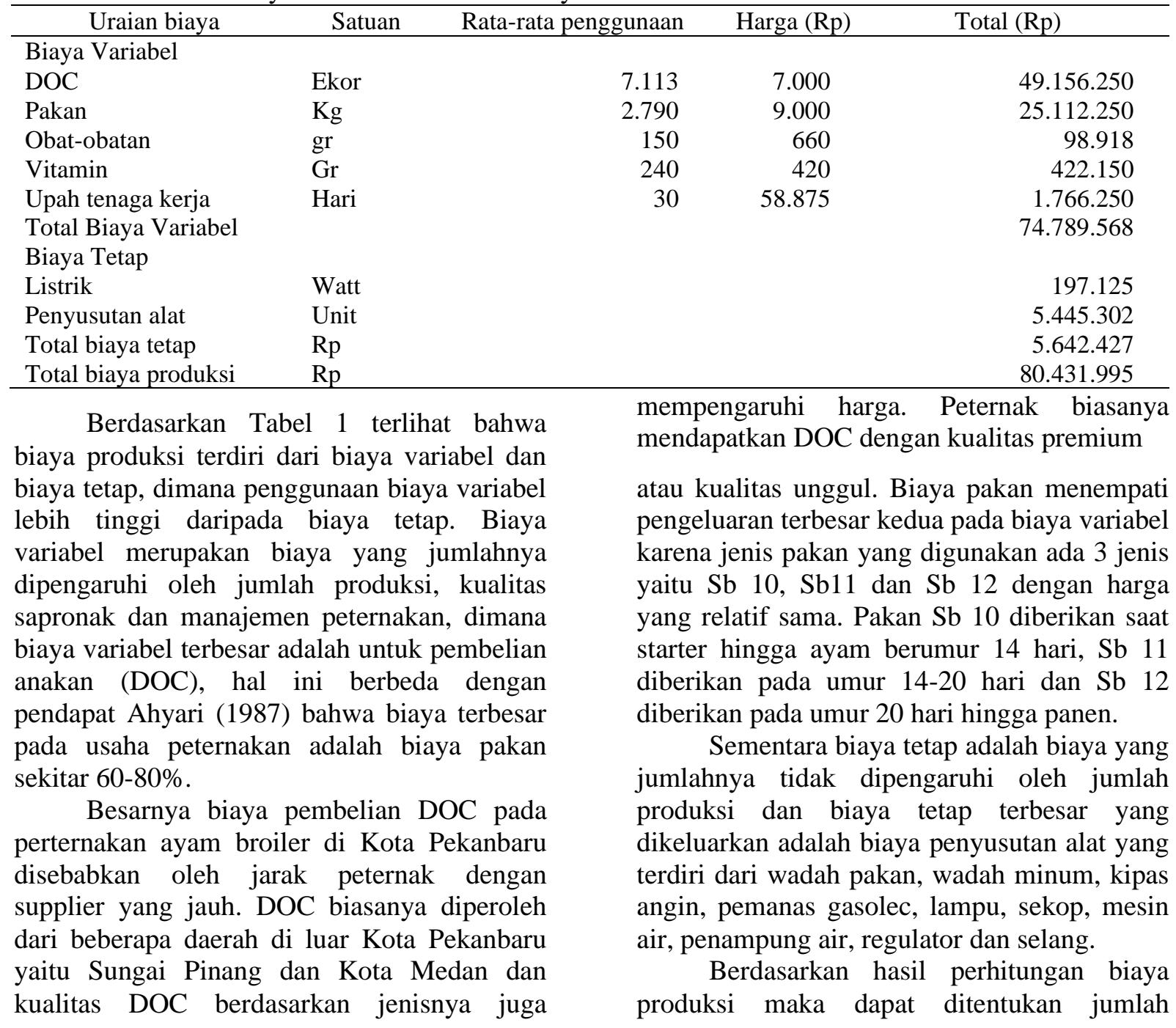


penerimaan, keuntungan dan R/C Ratio, seperti terlihat pada tabel berikut:

Tabel 2. Penerimaan, Keuntungan dan R/C Ratio Peternakan Ayam Broiler di Kota Pekanbaru.

\begin{tabular}{lcrrr}
\hline Uraian biaya & Satuan & Jumlah & Harga (Rp) & Total (Rp) \\
\hline Produksi: & & & & \\
$1 . \quad$ Ayam broiler & $\mathrm{Kg}$ & 11.260 & 18.000 & 202.680 .000 \\
2. Kotoran ayam & $\mathrm{Kg}$ & 14.083 & 250 & 3.520 .750 \\
Penerimaan & $\mathrm{Rp}$ & & & 206.200 .750 \\
Keuntungan & $\mathrm{Rp}$ & & & 125.768 .755 \\
R/C Ratio & & & & 2,56 \\
\hline
\end{tabular}

Hasil produksi peternakan ayam broiler terdiri dari ayam yang siap panen dan kotoran ayam yang dijual sebagai pupuk organik, dimana periode produksi berlangsung selama 5 minggu (35 hari) mulai dari datangnya DOC hingga panen. Produksi ayam broiler sebesar 11.260 ekor dengan tingkat harga yang berlaku adalah $\mathrm{Rp} 18.000 / \mathrm{kg}$.

Penerimaan merupakan keseluruhan hasil proses produksi selama satu periode dalam usaha peternakan ayam broiler. Penerimaan juga dianggap sebagai pendapatan kotor bagi peternak sebelum dikurangi dengan biaya produksi. Penerimaan yang diperoleh peternak merupakan akumulasi dari penerimaan produksi ayam bidup dengan kotoran ayam yaitu Rp 206.200.750. Peternak masih mendapatkan keuntungan karena penerimaan atau pendapatan bersih lebih besar daripada jumlah biaya produksi yaitu $\mathrm{Rp}$ 125.768.755. Keuntungan merupakan tujuan bagi setiap pelaku usaha khusunya pada peternakan ayam broiler dan ketika keuntungan diperoleh maka secara ekonomi usaha tersebut layak untuk dilanjutkan dan dikembangkan.

$\mathrm{R} / \mathrm{C}$ Ratio merupakan analisis yang digunakan untuk menentukan efisiensi usaha yakni dengan membandingkan jumlah penerimaan dengan besarnya biaya produksi. Nilai R/C ratio sebesar 2,56 artinya setiap Rp 1 biaya produksi yang dikeluarkan dalam proses produksi ayam broiler maka akan diperoleh penerimaan sebesar Rp 2,56 dan keuntungan sebesar $\mathrm{Rp}$ 0,56. Sehingga usaha peternakan ayam broiler layak dan tetap dapat dilanjutkan.

Analisis Break Even Point (BEP) atau titik impas merupakan teknik analisa untuk mempelajari hubungan antara besarnya total biaya dan keuntungan yang diharapkan dapat diperoleh sehingga membantu peternak untuk mengetahui volume penjualan dan volume produksi agar usaha tidak mengalami kerugian meskipun tidak mendapatkan keuntungan. Munawir (2002) menambahkan bahwa BEP adalah suatu keadaan operasi perusahaan dimana perusahaan tidak memperoleh laba dan tidak mengalami kerugian. Nilai BEP pada peternakan ayam broiler terlihat pada tabel berikut:

Tabel 3. BEP pada Peternakan Ayam Broiler di Kota Pekanbaru

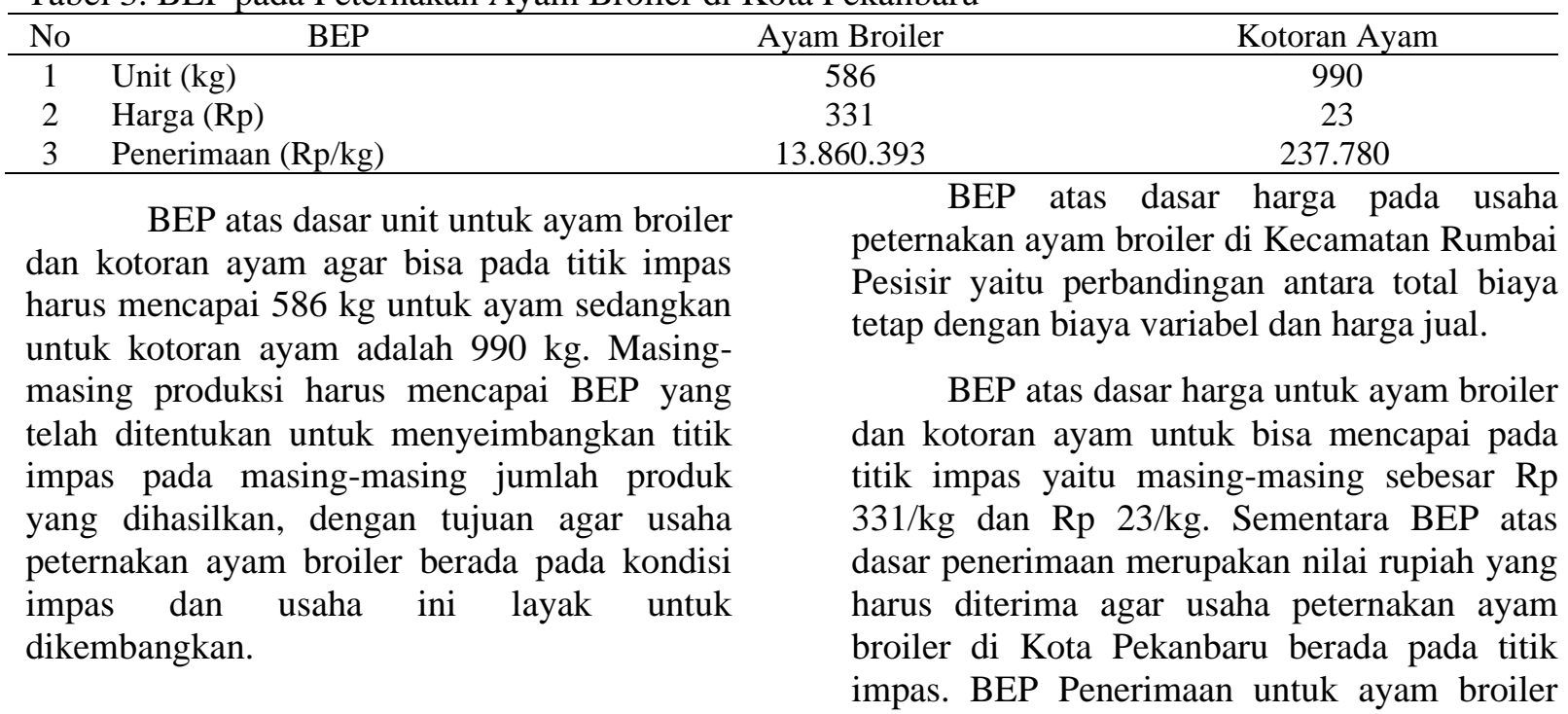


dan kotoran ayam agar bisa berada pada titik impas yaitu sebesar Rp 13.860.393/kg dan Rp $237.780 / \mathrm{kg}$. Hasil penelitian Ismail, dkk (2013) mengenai peternakan ayam broiler yang menggunakan 2 tipe kandang memberikan kesimpulan bahwa BEP harga, BEP produksi dan BEP ekor masing-masing peternak tidak mengalami kerugian.

Margin of Safety (MOS) merupakan batas aman usaha yang ditentukan berdasarkan penjualan yang ditargetkan atau direncanakan dengan penjualan pada titik impas. Menurut
Munawir (2002) bahwa penjualan yang telah ditargetkan membutuhkan informasi terkait jumlah maksimal target penjualan yang diperbolehkan mengalami penurunan namun tidak merugi. Perusahaan yang memiliki nilai MOS tinggi lebih baik dibandingkan perusahaan dengan nilai MOS rendah, artinya nilai MOS memberikan gambaran batas toleransi perusahaan tidak menderita kerugian tetapi juga belum mendapatkan keuntungan. Hasil perhitungan MOS usaha peternakan ayam broiler terlihat pada tabel berikut;

Tabel 4. Nilai MOS Peternakan Ayam Broiler di Kota Pekanbaru

\begin{tabular}{lrrr}
\hline \multicolumn{1}{c}{ Rincian } & Penjualan direncanakan & Penjualan BEP & MOS (\%) \\
\hline Unit (kg) & 11.260 & 586 & 94,8 \\
Harga (Rp) & 18.000 & 331 & 98,2 \\
Penerimaan (Rp/kg) & 202.680 .000 & 13.860 .393 & 93,2 \\
\hline
\end{tabular}

Berdasarkan Tabel 4 terlihat bahwa usaha peternakan ayam broiler di Kota Pekanbaru berada pada batas aman berproduksi, dimana nilai MOS penjualan dari sisi unit, harga dan penerimaan bernilai positif. Artinya agar penjualan ayam broiler tidak

merugi meskipun belum mendapatkan keuntungan maka setiap peternak perlu memperhatikan agar penjualan tidak kurang dari penjualan BEP.

\section{KESIMPULAN}

Hasil analisis ekonomi peternakan ayam broiler di Kota Pekanbaru sebagai berikut:

1. Total biaya produksi peternakan ayam broiler di Kota Pekanbaru sebesar Rp 80.431.995 yang terdiri dari Rp 78.789.568 biaya variabel dan $\mathrm{Rp} 5.642 .427$ biaya tetap, dimana biaya variabel tertinggi adalah pembelian DOC karena didatangkan dari luar Kota Pekanbaru. Penerimaan hasil produksi ayam broiler sebesar $\mathrm{Rp}$ 206.200.750 dimana Rp 200.680.000 merupakan nilai penerimaan ayam hidup dan Rp 3.520.750 didapat dari penjualan kotoran ayam yang digunakan sebagai pupuk organik. Nilai keuntungan sebesar $\mathrm{Rp} 125.768 .755$ dan $\mathrm{R} / \mathrm{C}$ ratio adalah 2,56 sehingga usaha dianggap layak untuk dilanjutkan dan dikembangkan

2. BEP unit sebesar 586 ekor ayam dengan harga $\mathrm{Rp} 331$ dan penerimaan $\mathrm{Rp}$ $13.860 .393 / \mathrm{kg}$. sedangkan untuk kotoran ayam didapat nilai BEP unit sebanyak 990 $\mathrm{kg}$ dengan harga $\mathrm{Rp} 23$ dan penerimaan $\mathrm{Rp}$ 237.780 .

3. Nilai MOS usaha peternakan ayam broiler termasuk kategori tinggi sehingga berada pada batas aman.

\section{DAFTAR PUSTAKA}

Ahyari A. 1987. Pengendalian Produksi. BPFE. Yogyakarta

Dinas Pertanian dan Perikanan Provinsi Riau. 2019. Populasi Peternakan Unggas di Pekanbaru. Pekanbaru

Ismail I, H.D Utami dan B. Utomo. 2013. Analisa Ekonomi Usaha Peternakan Broiler yang Mengggunakan Dua Tipe Kandang Berbeda. Jurnal Ilmu-Ilmu Peternakan, 23 (3): 11-16

Pekanbaru dalam Angka. 2021. Populasi Unggas Menurut Kecamatan dan Jenis Unggas (ekor) tahun 2018-2020. Pekanbaru

Putri E D, Cepriadi, F Restuhadi. 2020. Analisis Efisiensi Produksi Usaha ternak Ayam Ras Pedaging (Broiler) pada Pola Kemitraan Contract Farming di Kabupaten Kampar. Journal of Agribusiness and Community Empowerment, 3 (1): 60-70

Munawir. 2002. Analisa Laporan Keuangan. Liberty. Yogyakarta

Nawawi A.M, S. A Andayani, Dinar. 2017. Analisis Usaha Peternakan Ayam Petelur (Studi Kasus pada Peternakan Ayam Petelur Cihaur, Maja, Majalengka Jawa Barat). Jurnal Ilmu Pertanian dan Peternakan, 5 (1): 15-29 
